\title{
KOMUNITAS
}

\section{EKSPLOITASI EKONOMI DAN SEKSUAL PARA PENARI LENGGER}

\section{Eka Septianingsih $\bowtie$}

SMA Diponegoro 2 Sumpiuh Banyumas, Jawa Tengah, Indonesia

\section{Info Artikel}

Sejarah Artikel:

Diterima Juni 2012

Disetujui Juli 2012

Dipublikasikan September 2012

\section{Keywords:}

Lengger dancers;

Sosio-economic exploitation.

\begin{abstract}
Abstrak
Awalnya kesenian lengger digunakan dalam upacara-upacara ritual di pedesaan serta upacara-upacara yang berkaitan dengan kesuburan. Saat ini kesenian lengger lebih mengarah pada fungsi hiburan dan komersial. Hal ini membuat penari lengger rentan terhadap eksploitasi baik secara ekonomi maupun seksual. Pertanyaan penelitian ini adalah bagaimana bentuk pertunjukan lengger, bagaimana tanggapan masyarakat terhadap keberadaan penari lengger, bagaimana bentuk eksploitasi yang dialami oleh penari lengger, dan apa respon penari lengger tentang tindakan eksploitasi itu. Metode penelitian yang digunakan adalah kualitatif, dengan analisis data interpretatif. Lokasi penelitian di desa Selanegara, Sumpiuh, Banyumas. Hasil penelitian menunjukkan bahwa ada beberapa unsur yang terkait dengan bentuk pertunjukan lengger, yaitu: pemain, gerak, iringan musik, tata rias dan busana, serta tempat pementasan. Citra negatif penari lengger biasanya diasosiakan dengan gerakan tari yang erotis sehingga dapat memancing pelecehan, seperti diraba, dicolek, dipeluk dan dicium oleh para pengibing. Bentuk eksploitasi ekonomi terjadi karena tuntutan ekonomi sehingga mendorong para penari mengeksploitasi tubuhnya untuk mendapatkan uang. Perlakuan tidak senonoh dari penonton merupakan bagian dari resiko profesi yang harus dijalani. Fenomena ini diharapkan dapat mendorong masyarakat dan pemerintah untuk melindungi para pelaku kesenian dari tindakan eksploitasi.
\end{abstract}

\begin{abstract}
Originally lengger is performed in ceremonies and rituals in rural ceremonies associated with fertility. Currently the performance of lengger has more entertainment and commercial functions. This makes the dancers vulnerable to exploitation lengger both economically and sexually. The objectiveof this study is to explore the form of lengger show, forms of exploitation experienced by dancers lengger, and the responses of the lengger dancer towards exploitation. Research methods used are qualitative approach, with interpretive data analysis. Research was done in the village Selanegara, Sumpiuh, Banyumas. The results show that there were some elements associated with this form lengger performances, namely: players, body movement, music, makeup and fashion, as well as staging. The negative image normally rise from lengger dancer's erotic movements, which are responded by various form,s of abuse, such as touched, poked, hugged and kissed by pengibing. Economic exploitation occurs due to the economic demands so that the dancers exploit her body to get money. Dances of Lengger are very prone to sexual and economic ebuse. This phenomenon should encourage the public and the government to rethink how to to protect the dancers from exploitation.
\end{abstract}

(C) 2012 Universitas Negeri Semarang 


\section{PENDAHULUAN}

Kesenian, terutama tari merupakan pola-pola simbolik untuk memelihara keseimbangan dalam hidup secara komunal yang melambangkan harapan kesuburan, penghindaran mala petaka, dan lain-lain. Tari pada jamannya merupakan bagian utama dari upacara- upacara inisiasi dari kehidupan (kelahiran, kematian, perkawinan, dan sebagainya). Kesenian lengger sebagai suatu bentuk seni pertunjukan rakyat pada awalnya berkembang di daerah pedesaan dan akrab dengan nilai-nilai budaya petani yang pada masa lalu selalu dikaitkan dengan kepercayaan, alam gaib dan dunia roh. Kesenian lengger dipuja dan erat hubungannya dengan permohonan kesejateraan bagi suatu kelompok masyarakat melalui berbagai upacara ritual seperti bersih desa, baritan, marungan dan upacara kaulan. Fungsi utama dari kesenian lengger tetap merupakan komponen dalam agricultural ceremonies (semacam upacara kesuburan). Nilai-nilai yang bersifat mistis menjadi petunjuk bahwa lengger berasal dari masa praHindu, yang dalam kaitannya dengan ritus kesuburan, hubungan antara pria dan wanita diyakini sebagai cara untuk mewujudkan impian dalam mencapai keselarasan hidup (Sunaryadi, 2000:35).

Bentuk pertunjukan dan fungsi lengger dari masa ke masa telah mengalami perkembangan. Sekarang tidak lagi diperuntukan untuk upacara-upacara ritual semata, tetapi sudah dipandang sebagai suatu seni yang dinikmati atau ditonton masyarakat pendukungnya. Dengan demikian pertunjukan kesenian lengger yang diutamakan adalah keindahan gerak dalam tari lengger yang dinikmati atau ditonton. Disamping keindahan gerak juga termasuk unsur pendukung pertunjukan lengger baik iringan, rias, busana maupun tempat pertunjukan. Dengan demikian pertunjukan kesenian lengger tidak lagi berkaitan dengan upacara ritual semata seperti jaman dahulu, melainkan sudah berfungsi sebagai tontonan atau sebagai tari hiburan bahkan berfungsi sebagai sarana pendidikan dan digunakan untuk bahan pembelajaran pada sekolah tari yang ada di daerah Banyumas. Menurut Indriyanto (2005 : 65), tari Banyumasan ditampilkan dalam acara festival-festival tingkat daerah, nasional bahkan hingga tingkat internasional. Selain itu juga untuk materi/bahan ajar pada sekolah-sekolah menengah sampai pendidikan tinggi yang memiliki program seni pertunjukan, sedangkan fungsi lain digunakan juga untuk sajian penyambutan tamu, peresmian kantor, upacara pernikahan dan lain-lain.

Tari yang biasanya terkait dengan unsur ekspresi jiwa dan kesenangan, dewasa ini telah berkembang dalam bentuk tarian pendidikan bahkan bentuk kesenian ini juga telah merambah pada area ekonomis dimana berfungsi sebagai alat untuk mencari nafkah, seperti jenis tari barangan. Jenis tarian pendidikan bertujuan untuk menyenangkan anak didik, oleh karena itu, apabila jenis tarian ini tidak menimbulkan rasa senang berarti tujuannya tidak tercapai. Begitu pula menari atau menciptakan tarian untuk tujuan mencari nafkah, tentu saja bermaksud membuat senang bagi yang memerlukan atau yang memberi imbalan (Hadi, 2005:18). Tari lengger merupakan jenis tari barangan, yaitu jenis tarian yang dibawakan dengan cara berkeliling dari satu tempat ke tempat yang lain. Selain bertujuan untuk menghibur para penikmatnya, tari lengger juga digunakan untuk mencari nafkah oleh para pelakunya. Tari lengger yang ada di Desa Selanegara Kecamatan Sumpiuh Kabupaten Banyumas juga lebih banyak berfungsi sebagai mata pencaharian atau sebagai sumber nafkah bagi para penarinya yang semuanya adalah perempuan.

Berdasarkan latar belakang tersebut maka pertanyaan penelitian yang akan dijawab dalam penelitian ini adalah bagaimana bentuk pertunjukan tari lengger Banyumasan di desa Selanegara Kecamatan Sumpiuh Kabupaten Banyumas, bagaimana tanggapan masyarakat Desa Selanegara Kecamatan Sumpiuh Kabupaten Banyumas terhadap keberadaan penari lengger Banyumasan, bagaimana bentuk eksploitasi yang dialami oleh penari lengger, dan bagaimana pendapat penari lengger tentang tindakan eksploitasi yang diterimanya. 
Tabel 1. Lima bentuk eksploitasi

\begin{tabular}{|c|c|}
\hline BENTUK & PENGERTIAN \\
\hline $\begin{array}{l}\text { Eksploitasi } \\
\text { Seksual }\end{array}$ & $\begin{array}{l}\text { Mereka yang terlibat dalam kegiatan prostitusi, pelayanan/pekerja } \\
\text { seks, atau menjadi obyek kegiatan pornografi yang dikarenakan } \\
\text { oleh ancaman pemaksaan, penculikan, diperlakukan dengan salah, } \\
\text { menjadi orang yang dijual (debt bondage) atau karena menjadi korban } \\
\text { penipuan. }\end{array}$ \\
\hline $\begin{array}{l}\text { Kerja Paksa } \\
\text { (forced labour) }\end{array}$ & $\begin{array}{l}\text { Segala bentuk pekerjaan atau pelayanan yang didapat (pelaku) dengan } \\
\text { menggunakan tenaga orang yang berada di dalam ancaman hukuman } \\
\text { dan orang tersebut bekerja melayani tanpa keinginannya sendiri secara } \\
\text { sukarela. }\end{array}$ \\
\hline $\begin{array}{l}\text { Perbudakan } \\
\text { (slavery) }\end{array}$ & $\begin{array}{l}\text { Keadaan (status) dan kondisi seseorang terhadap siapa hak pemilikan } \\
\text { (dari orang lain) diberlakukan terhadapnya. }\end{array}$ \\
\hline Penghambaan & $\begin{array}{l}\text { Status atau kondisi orang (-orang) yang berdiam di atas tanah milik } \\
\text { orang lain yang menurut hukum kebiasaan atau perjanjian terikat } \\
\text { untuk hidup dan bekerja di atas tanah tersebut dan wajib mengabdi } \\
\text { kepada orang tersebut, baik dengan imbalan maupun tidak dan ia } \\
\text { tidak bebas mengubah statusnya itu. }\end{array}$ \\
\hline Pengambilan & Trafiking dari pengambilan organ-organ tubuh hanya muncul jika \\
\hline Organ-organ & seseorang dipindahkan untuk tujuan pemindahan organ dan protokol \\
\hline Tubuh & $\begin{array}{l}\text { ini tidak mengatur jika hanya berupa pemindahan organ (organ yang } \\
\text { dipindahkan sudah tidak berada dalam tubuh lagi). }\end{array}$ \\
\hline
\end{tabular}

Sagala dan Rozana (2007) menyebutkan, terdapat lima bentuk eksploitasi sebagaimana terlihat pada Tabel 1.

Selanjutnya, bahwa eksploitasi ini juga terkait erat dengan eksploitasi tubuh, khususnya bagi perempuan. Salah satu hal yang dapat kita lihat adalah bahwa seni pertunjukkan menjadi salah satu arena dimana tubuh perempuan sering kali dijadikan sebagai obyek eksploitasi, terutama dalam seni pertunjukkan yang sarat akan erotisme. Menurut Arivia (dalam Irianto, 2005:10) berbagai kalangan mempergunakan tubuh perempuan sebagai komoditas yang dieksploitasi habis-habisan

Selain sebagai komoditas, tubuh perempuan sering dilekatkan dengan ancaman kekerasan. Pada saat berada di tempat kerja, perempuan sering mengalami eksploitasi dan kekerasan dari pengguna jasa. Salah satu bentuk kekerasan yang dialami adalah kekerasan seksual (Sagala dan Rozana, 2007:96). Selain mengalami eksploitasi seksual, seorang perempuan juga mengalami eksploitasi ekonomi, terutama dalam lingkungan kerja yang kurang menghargai kemampuan seorang perempuan dan selalu menempatkan perempuan pada posisi yang rendah dengan beban kerja yang berat, namun upah yang diterima tidak sebanding dengan beban kerja yang diterima.

\section{METODE PENELITIAN}

Pendekatan penelitian ini adalah pendekatan kualitatif. Lokasi penelitian di Desa Selanegara Kecamatan Sumpiuh Kabupaten Banyumas. Alasan pemilihan lokasi penelitian ini adalah adanya kelompok kesenian lengger yang hingga kini masih bertahan di daerah tersebut, penari lengger di desa ini terkenal akan keluwesan dan kecantikannya, dan harga yang ditawarkan oleh kelompok kesenian lengger di desa ini 
pun lebih terjangkau jika dibandingkan dengan kelompok lain. Sumber data yang dimanfaatkan peneliti berasal dari informan utama yaitu para penari lengger, dan informan pendukung dari pengibing, anggota kelompok kesenian, tokoh dan beberapa warga masyarakat. Data sekunder yang digunakan dalam penelitian ini adalah berupa bukubuku yang terkait dengan penelitian ini, serta dokumen dan sumber lain yang relevan.

Dalam penelitian ini penulis menggunakan metode mengumpulkan data berupa metode observasi, wawancara, dan dokumentasi. Wawancara bersifat terbuka dan indepth interview. Analisis data menggunakan model interaktif melalui tahap-tahap pengumpulan data, reduksi data, penyajian data dan penarikan kesimpulan. Validitas data yang diterapkan adalah dengan triangulasi sumber.

\section{HASIL DAN PEMBAHASAN}

Letak Desa Selanegara yang berada di daerah dataran tinggi dan jauh dari pusat pemerintah kabupaten berpengaruh pada karakteristik kehidupan masyarakat setempat, baik itu yang terkait secara sosial, ekonomi, maupun budaya. Letak geografis desa dan keadaan tanah yang cukup subur merupakan faktor utama yang mendorong bagi masyarakat setempat untuk bertani. Latar belakang sosial ekonomi dan budaya masyarakat yang khas pedesaan menjadikan karakteristik yang khas dan unik dari masyarakat ini. salah satu hal yang menarik adalah fenomena berkembangnya seni budaya sebagai wujud dari ekspresi jiwa masyarakat yang dijadikan sebagai sarana hiburan. Bagi masyarakat setempat, kesenian yang berkembang menjadi sarana hiburan rakyat, diantaranya adalah seperti ebeg (kuda lumping), lengger, campur sari, serta dangdut. Masyarakat Selanegara masih belum banyak mengenal jenis-jenis hiburan modern seperti yang ada di kota besar karena ruang lingkup pergaulan masyarakat yang masih sempit dan masih sedikit pengaruh kota yang terlihat pada kehidupan masyarakat.

Jumlah penari lengger yang ada dan menetap di Desa Selanegara Kecamatan
Sumpiuh Kabupaten Banyumas saat ini berjumlah dua orang, yaitu Sartini dan Parti. Dahulu, ada seorang lagi lengger yang menetap di Desa Selanegara, yaitu lengger Sani, tetapi kemudian pindah dan menetap di Cilacap karena menikah dengan orang Cilacap. Di Desa Selanegara terdapat group kesenian lengger yang bernama "Laras Agung Budhoyo". Meskipun hanya terdapat dua orang penari lengger dari desa setempat, tetapi dalam setiap pementasan group "Laras Agung Budhoyo", terdapat sekitar 2-4 orang penari lengger. Beberapa penari yang berasal dari luar desa juga ikut bergabung dalam group "Laras Agung Budhoyo", dan ikut tampil bersama group tersebut setiap kali mengadakan pertunjukan tari.

Pendapat mengenai muncul dan berkembangnya kesenian lengger di Banyumas dan sekitarnya ini memiliki beberapa variasi asumsi. Sebagian orang menyebutkan, lengger muncul di daerah Jati Lawang suatu daerah minus di wilayah Banyumas. Sebagian lagi berpendapat kesenian lengger berasal dari Mataram masuk ke Kali Bagor daerah Banyumas pada tahun 1755. Bagi masyarakat, perbedaan asumsi atas asal muasal dan perkembangan kesenian lengger ini tidak lantas menjadi bahan perdebatan dan penghambat atas perkembangan jenis kesenian ini. Penamaan lengger itu sendiri, diyakini juga memiliki alasan yang bervariasi. Beberapa kelompok seniman Banyumas menafsirkan lengger berasal dari kata leng dan jengger, leng (jawa) berarti lubang, jengger (jawa) merupakan ciri sekunder pada ayam jantan. Menurut mereka leng identik dengan alat vital wanita, sedang jengger melambangkan sifat kejantanan. Dua kata itu diartikan sebagai: "dikira leng ning jengger" (dikira lubang tetapi jengger) artinya dikira perempuan ternyata laki-laki. Hal itu ditunjukan pada fisik peran wanita yang dimainkan oleh laki-laki (Sunaryadi, 2002:32).

Terkait dengan pertunjukan tari lengger, unsur-unsur di dalamnya meliputi: pemain, gerak, iringan/musik, tata rias dan busana, serta tempat pementasan. Para pemain yang terlibat dalam pertunjukan tari lengger meliputi penari lengger yang biasanya 
terdiri atas dua sampai dengan empat orang penari, badhut yaitu seorang penari lakilaki yang berperan sebagai pelawak, karena dalam penampilanya badhut sering kali melontarkan banyolan-banyolan lucu serta bertingkah laku lucu, selain itu badhut juga merangkap sebagai penari kuda calung. Selanjutnya, ada juga seorang penari baladhewan yang biasanya muncul pada babak akhir pementasan lengger, dan yang terakhir adalah penayagan, yaitu orang-orang yang bertugas mengiringi pertunjukan lengger dengan menabuh alat musik khas pengiring tari lengger yaitu calung. Penayagan dalam sebuah group kesenian lengger biasanya terdiri dari 16-20 orang.

Menurut lengger Parti (30 tahun), gerakan tari yang ada pada pertunjukan tari lengger pada dasarnya mengambil dari gerakan tari gambyong, tetapi dalam tari lengger gerakan-gerakanya belum berpola secara rapi dan sering kali bersifat spontanitas dan improvisasi. Hal ini tampak pada saat para pengibing mulai ikut menari bersama para lengger di atas panggung. Gerakangerakan yang ditarikan lebih merupakan luapan ekspresi pribadi para penari. Media gerak dalam pertunjukan lengger adalah tubuh lengger, melalui eksplorasi dari bagianbagian tertentu dari tubuh akan terbentuk satu gerakan yang indah. Pinggul merupakan salah satu bagian tubuh yang memiliki dominasi gerak khas tarian lengger. Pinggul yang digoyang dengan berbagai variasi gaya menjadi daya tarik bagi penonton. Pertunjukan tarian lengger dapat dilihat pada Gambar 1.

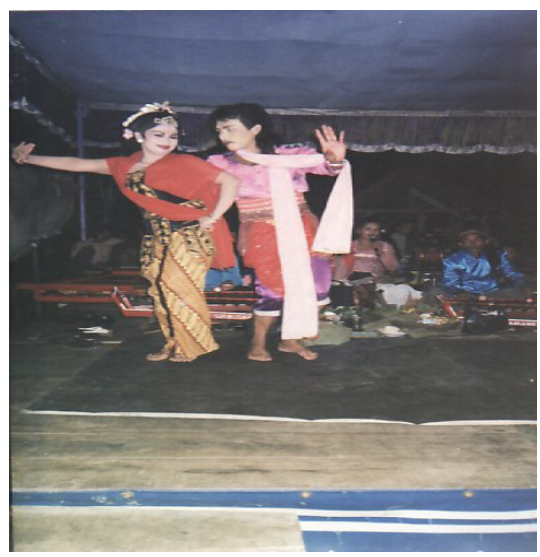

Gambar 1. Goyangan pinggul penari lengger
Tari lengger berdurasi antara 4-8 jam tergantung pada waktu pementasanya. Jika pementasan dilakukan pada siang hari, maka pentas diadakan mulai dari pukul 1 siang sampai dengan pukul 5 sore. Jika pementasan dilakukan pada malam hari, pentas diadakan milai dari pukul 8 malam sampai dengan pukul 4 pagi. Pentas pada siang hari memiliki waktu yang lebih singkat dan harga yang lebih murah dibandingkan dengan pentas pada malam hari. Pementasan pada malam hari dilakukan setelah waktu shalat isya' sampai dini hari.

Alat musik dasar yang digunakan untuk mengiringi jalannya pentas adalah alat musik calung, namun seiring dengan perkembangan jaman dan berkembangnya berbagai jenis alat musik, kemudian ditambahkan beberapa instrumen moderen seperti organ, drum, terompet dan gitar sebagai alat musik pengiring tari lengger. Calung merupakan alat musik tradisional terbuat dari bambu yang cara membunyikanya dengan cara dipukul.

Dalam seni pertunjukan, tata rias dan busana merupakan media ungkap penari lengger agar dapat menarik perhatian penonton atau pengibing, disamping untuk memperkuat ekspresi. Riasan wajah yang biasa digunakan oleh para penari lengger adalah riasan wajah yang tebal dan tegas sehingga terlihat "menor", ditambah lagi dengan hiasan sanggul yang semakin mempercantik penampilan wajah lengger. Bagian-bagian tubuh lengger yang terbuka dipoles dengan menggunakan lulur berwarna kuning langsat, sehngga akan terlihat lebih cerah dan menarik. Hal ini mempertegas karakter seorang lengger yang identik dengan karakter yang centil dan menggoda, terutama bagi kaum laki-laki. Busana yang digunakan penari dalam pertunjukkan lengger terdiri atas kemben, jarik, sampur (selendang) dan streples. Tahapan-tahapan dalam pertunjukan tari lengger yaitu: gambyongan, badhutan ebegebegan, dan baladhewan.

Latar belakang yang mendorong perempuan menjalani profesi sebagai penari lengger Banyumasan adalah faktor ekonomi dan tingkat pendidikan yang rendah. Faktor ekonomi keluarga dimana pendapatan suami yang hanya sebagai sopir atau sebagai buruh 
pabrik tidak dapat menutupi kebutuhan keluarga, maka mendorong perempuan untuk ikut serta dalam memenuhi nafkah keluarga. Salah satunya adalah dengan menjalani profesi sebagai penari lengger. Walaupun profesi ini sering kali mendapat pandangan negatif baik dari masyarakat, namun Sartini dan Parti serta oleh rekanrekannya yang lain mengambil resiko ini karena desakan ekonomi keluarga yang kurang serta kebutuhan hidup yang semakin kompleks. Sementara itu, budaya patriarkhi yang menomorduakan perempuan juga menjadi sebab para perempuan memiliki profesi yang dianggap sepele oleh masyarakat seperti menjadi penari lengger. Tingkat pendidikan yang dimiliki oleh para penari lengger, hanyalah lulusan Sekolah Dasar dan Sekolah Menengah Pertama. Dengan ijazah yang dimiliki oleh penari lengger, tentu saja akan sangat sulit untuk dapat bersaing dalam bursa kerja, oleh karena itu dengan bermodalkan kemampuan menari para perempuan ini menjalani profesinya sebagai penari lengger.

Eksploitasi yang dialami oleh para penari lengger ini meliputi eksploitasi seksual dan eksploitasi ekonomi. Eksploitasi seksual terjadi melalui tindakan-tindakan, baik yang berupa ucapan (verbal) seperti lelucon cabul dari badhut, siulan penonton, serta kata-kata kotor dari penonton, maupun yang berupa tindakan seperti rabaan, cubitan, colekan, bahkan ada beberapa pengibing ataupun badhut yang berani memeluk dan mencium penari lengger. Dalam tahap badhutan misalnya guyonan yang ditampilkan bernada melecehkan perempuan dengan menggunakan bagian tubuh (payudara) sebagai bahan lelucon. Contohnya adalah pada dialog di bawah ini :

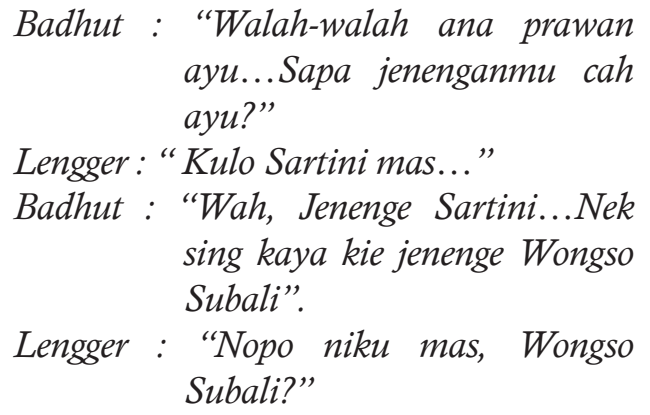

Badhut : "Walah-walah ana prawan ayu...Sapa jenenganmu cah ayu?"

Lengger : "Kulo Sartini mas..."

Badhut : "Wah, Jenenge Sartini...Nek sing kaya kie jenenge Wongso Subali".

Lengger : "Nopo niku mas, Wongso Subali?"
Badhut : "Wongso Subali kue....Wonge ora Sepira'o susune se-bal volly...".
(Sumber : data penelitian)

Penggunaan kata-kata yang kurang sopan apalagi mengeksploitasi tubuh perempuan ini masih sering terjadi pada pertunjukkan ini. Bahkan pada masa terdahulu, terdapat tradisi suwelan yaitu memberi uang kepada para penari dengan menyelipkan uang diantara payudaranya, bahkan sambil menyelipkan uang mereka meraba bagian tubuh tersebut. Kini, tradisi suwelan dalam kesenian lengger sudah dilarang.

Eksploitasi seksual dalam pertunjukan tari lengger tampak mulai dari penggunaan kostum penggung, gerakan tari sampai dengan interaksi penari dengan penonton maupun dengan partner menari laki-laki (badhut). Kostum yang dikenakan oleh penari lengger seolah ingin mempertontonkan aurat perempuan yang seharusnya ditutup dan tidak diperlihatkan kepada banyak orang, gerakan-gerakan tari para penari lengger juga sering mengundang hasrat seksual para penonton karena gerakan-gerakan tari yang dibawakan sering kali menyimpang dari gerakan yang sudah ditentukan, seperti dengan menambahkan gerakan kayang, ataupun goyangan patah-patah dan goyang ngebor seperti penyanyi dangdut. Selain itu interaksi penari dengan badhut di atas panggung sering kali menampilkan adeganadegan seperti memeluk, mencium pipi, memegang pantat, dan lain sebagainya, ditambah dengan para pengibing yang sering nekat naik ke atas panggung meski sudah dilarang.

Bentuk eksploitasi ekonomi tampak ketika para penari lengger harus bekerja dari pagi hingga sore ataupun dari malam hinggga pagi menjelang dengan selang waktu sekitar 4-8 jam setiap kali pementasan, dan dengan tahapan-tahapan yang harus dilalui tanpa ada waktu untuk istirahat tentunya akan sangat melelahkan bagi para penari, bahkan pernah tidak pulang selama hampir satu minggu karena harus berpindah-pindah dari tempat pentas yang satu ke tempat pentas yang 
lain. Namun rasa lelah seolah tidak pernah dirasakan oleh para penari lengger ketika menyadari bahwa beban perekonomian keluarga berada di pundaknya.

Tindakan kurang sopan tidak hanya hadir dari pihak penonton saja, tetapi dari pihak penari sendiri juga kerap melakukan gerakan-gerakan tari yang kurang sopan dan cenderung erotis. Goyangan-goyangan erotis yang dihadirkan oleh para penari inilah yang kemudian memancing penonton maupun pengibing untuk melakukan hal-hal yang melecehkan penari baik yang berupa ucapan maupun yang berupa tindakan. Goyangan pinggul yang merupakan ciri khas dari tari lengger sering dugunakan oleh para penari untuk menarik perhatian para pengibing maupun penonton yang mayoritas adalah kaum laki-laki. Goyangan-goyangan pinggul yang dilakukan oleh para penari lenggerseperti goyang ke kanan dan ke kiri, ke depan dan ke belakang, serta goyangan memutar pinggul. Selain goyangan pinggul, penari lengger juga kerap melakukan goyangan-goyangan yang dimodifikasi sendiri seperti, kayang, goyang ngebor seperti Inul Daratista, serta goyangan erotis lain yang ditiru dari penyanyi dangdut. Adanya perilaku yang tidak sopan seperti itulah yang kemudian menimbulkan pandangan miring dari masyarakat sekitar terutama dari kaum wanita dan kaum ulama atau pemuka agama terhadap para penari lengger.

Seorang penari lengger yang sedang menghibur di panggung menyadari bahwa dirinya adalah milik masyarakat. Segala hal yang ditampilkan oleh penari akan menjadi pusat perhatian dari berbagai pasang mata penonton yang menyaksikan. Setiap perilaku penari di atas panggung dapat memunculkan berbagai macam persepsi dalam masyarakat baik yang positif maupun yang negatif. Persepsi atau pandangan masyarakat yang terkadang bernada miring (negatif) tidak lagi menjadi sebuah bumerang atau hambatan bagi seorang perempuan untuk mempertahankan profesinya sebagai seorang penari lengger. Menurut Suraji (2006 : 61), masyarakat pada umumnya mempunyai kesan kurang baik terhadap tarian lengger. Tarian lengger di mata masyarakat identik dengan "kemesuman". Lebih lanjut menurut Suraji (2006), pandangan masyarakat yang negatif tersebut menjadi tantangan paling berat yang dialami oleh para penari lengger. Walaupun lengger tidak seperti digambarkan oleh masyarakat tetapi untuk memulihkan citra negatif tersebut seringkali tidak mudah.

Lebih lanjut dijelaskan bahwa pada dasarnya kesenian yang berkembang di daerah Banyumas berbeda dengan corak Jawa pada umumnya. kesenian di Jawa, khususnya Jawa Tengah merupakan adopsi dari kesenian keratin. Sedangkan kesenian Banyumasan ini memiliki ciri unik yang berbeda, yaitu soal kebebasan. Menurut Priyadi (2003), Di samping dari segi bahasa, kesenian Banyumas juga menunjukkan nafas kebebasan. Musik gamelan, suara penyanyi waranggana yang lugas, teriakanteriakan gembira atau tepukan tangan para penabuh gamelan mencerminkan karakter kebebasan gaya Banyumasan. Tembangtembang Banyumasan lama, seperti Kembang Glepang atau ilogondhang menggambarkan dialog yang terbebas dari kekangan seni yang dianggap adiluhung sebagaimana dilakukan para seniman di keraton. Oleh karena itu, perbedaan ini juga menjadi salah satu faktor yang membuat kesenian Banyumasan memiliki citra yang negatif.

Bentuk kesenian tari lengger, baik dari busana maupun dari gerakan tarinya ngundang pandangan yang bervariasi dari berbagai pihak. Bagi kaum ulama, kesenian ini tidak sesuai dengan kaidah agama dan lengger dianggap sebagai tarian untuk pembangkit birahi para laki-laki yang menyaksikannya. Bagi kaum berpendidikan, kesenian tradisional identik dengan kesenian kraton yang menggambarkan penari sebagai sosok yang cantik, anggun, penuh kelembutan, kehalusan, namun dalam kenyataannya kesenian ini dianggap sebagai wujud emosional dan kebinalan penari yang dapat membut lawan jenis terpikat. Hal ini dikarenakan penampilan penari yang cenderung erotis baik dari segi busana maupun bentuk tarianya. Bagi Sartini (30 tahun, 25 April 2008) yang telah menjalani profesi sebagai penari lengger selama 13 tahun, profesi yang dijalaninya memang 
sering mendapatkan pandangan miring dari masyarakat, tetapi pandangan miring tersebut biasanya datang dari masyarakat luar desanya yang tidak mengetahui kehidupan sehari-harinya di dalam keluarga.

Bagi penari lengger, perilaku di atas panggung merupakan tuntutan profesi, sedangkan pada saat berada di rumah, apa yang dijalaninya merupakan kewajiban sebagai ibu rumah tangga. Bahkan, ketika penari lengger selesai pertunjukan dan pulang ke rumah, pekerjaan rumah sudah menunggu dan harus kembali beraktivitas di rumah seperti mencuci, memasak, mengurus anak, serta melayani suami.

Menurut lengger Sartini (30 tahun, 25 April 2008), pandangan negatif yang ada dalam masyarakat itu sama sekali tidak benar jika dibandingkan dengan kenyataan kehidupan sehari-harinya di luar pentas yang sama sekali jauh dari hal-hal yang berbau maksiat. Bagi seorang lengger senior seperti Sartini dan Parti, sebisa mungkin untuk tidak melakukan hal-hal yang bertentangan dengan agama seperti berbuat maksiat maupun berzina.

Namun, akhir-akhir ini banyak muncul lengger-lengger junior yang tidak memiliki dasar seorang penari, melainkan para penyanyi organ tunggal dan biduan dangdut yang kemudian berpindah profesi menjadi penari lengger. Para biduan dangdut tertarik untuk menjadi penari lengger karena jumlah pendapatan seorang penari lengger lebih besar jika dibandingkan dengan seorang biduan dangdut. Pendapatan yang diperoleh penari lengger dalam satu kali pentas mulai dari Rp. 200.000 sampai dengan Rp. 500.000, tentunya lebih besar jika dibandingkan dengan seorang biduan dangdut yang hanya memperoleh RP. 150.000 sampai dengan Rp. 250.000 setiap kali pentas. Para lengger junior inilah yang kemudian kerap melakukan tindakan-tindakan yang kurang sopan di atas panggung, seperti menampilkan goyangangoyangan dangdut seperti goyang ngebor, goyang patah-patah, serta gerakan-gerakan yang seolah menggambarkan orang yang sedang bercinta.

Bagi penari, ketika mendapatkan perlakuan yang kurang senonoh dari para pengibing maupun penonton, para penari tidak merasa sebagai pihak yang terlecehkan. Bagi seorang penari yang terpenting adalah bagaimana menjaga diri masingmasing dengan baik. Penari akan berusaha menghindar sedini mungkin jika penonton mulai bertindak tidak senonoh dan akan berusaha melakukan penolakan secara halus. Bagi para penari, adalah hal yang wajar apabila pengibing kemudian berusaha untuk menyentuh ataupun memegang para penari. Sebagaimana dikatakan oleh Samini (30 tahun, 6 Mei 2008), jika tidak siap untuk dipegang atau diraba-raba oleh penonton, maka lebih baik tidak usah menjadi penari, karena sudah menjadi resiko seorang lengger ketika ada penonton yang bertindak kurang sopan, terlebih lagi jika penonton tersebut dalam keadaan mabuk, maka apapun bisa terjadi.

Berkaitan dengan alternatif alih profesi, jawaban yang sama dilontarkan oleh para penari. Tidak pernah terlintas dalam pikiran untuk berpindah profesi, apalagi benar-benar beralih profesi. Bagi para penari, penghasilan yang relatif banyak dapat mereka dapat dari pekerjaan ini sehingga dapat menutupi kekurangan dari pendapatan suami, bahkan pendapatan menjadi penari lebih besar jika dibandingkan dengan pendapatan suami yang rata-rata adalah petani ataupun buruh (angkut, bangunan, dan lain sebagainya).

Para penari lengger tidak pernah menyadari bahwa apa yang dijalaninya selama ini sarat akan tindakan-tindakan eksploitasi, diantaranya adalah eksploitasi seksual dan eksploitasi ekonomi. Bentuk eksploitasi seksual yang berupa penggunaan busana yang mewajibkan untuk menampakkan setiap lekukan tubuh bahkan tidak sedikit membuka bagian-bagian tubuh yang tidak seharusnya terbuka seperti dada dan betis, bahkan payudara yang sedikit menyembul, belum lagi tindakan-tindakan tidak senonoh dari para penonton maupun para pengibing dianggap oleh para penari lengger sebagai sebuah konsekuensi yang harus dijalani. Sedangkan bentuk eksploitasi ekonomi yang dialami oleh penari lengger berupa tuntutan kerja yang banyak menguras tenaga dan waktu, belum lagi kurangnya 
waktu untuk istirahat, dianggap oleh penari lengger sebagai kewajiban mencari nafkah untuk keluarga. Para penari lengger tidak pernah sedikitpun merasa tereksploitasi atau dimanfaatkan baik oleh keluarga maupun oleh pihak-pihak lain yang terkait dengan profesi seorang penari lengger.

Hal ini senada dengan yang diungkapkan oleh Ratih (2005) dalam penelitiannya tentang penari Tayub di derah Blora yang sering juga disebut dengan seorang joged atau ledhek. Sebagai seorang joged pasrah saja ketika dirinya dicolek, dipeluk, dirangkul bahkan dicium oleh pengibing yang terlalu berani dan kebanyakan sudah mabuk berat. Bagi joged atau ledhek tujuan utamanya menjadi seorang penari tayub adalah semata-mata mencari nafkah untuk menghidupi keluarganya. Mereka rela menari tayub semalaman, atau seharian hanya sekedar mendapatkan upah yang bisa untuk mencukupi kebutuhan sehari-hari.

Nilai penting yang tidak dapat dilupakan, bahwa pada hakikatnya semua pertunjukan tradisional memiliki makna atau nilai, yang dapat diamati melalui gerak, iringan, tata rias dan tata busana yang ditampilkan. Dan yang paling penting adalah bahwa hal itu merupakan bagian dari kearifan lokal budaya bangsa yang harus dilestarikan keberadaannya. Bahkan bagi bangsa sebesar ini, kesenian tradisional haruslah memiliki tempat terhormat di masyarakatnya sendiri. Salah satu pelestarian budaya Banyumasan yang dapat dilakukan adalah dengan pemberian materi muatan lokal pada jenjang sekolah. Tukiran dan Kosasih (2007) menjelaskan bahwa materi muatan lokal Banyumasan pada jenjang sekolah dasar mendapatkan respon yang positif. Pengenalan budaya lokal pada masyarakat khusunya anak didik pada level pendidikan dasar merupakan langkah konkrit yang memberikan stimulan yang baik pada pelestarian budaya tradisional, khususnya budaya Banyumasan.

\section{SIMPULAN}

Peminat tari lengger datang dari bebagai lapisan masyarakat, dan dari berbagai lapisan umur, terutama kaum laki-laki. Akan tetapi, tari lengger oleh beberapa pihak dinilai negatif serta bertentangan dengan norma agama yang ada di dalam masyarakat karena dalam pementasan lengger selalu sarat akan kemaksiatan. Penampilan penari lengger yang dinilai seronok menjadikan citra negatif di mata masyarakat. Terdapat dua bentuk eksploitasi yang dialami oleh para penari lengger, yaitu eksploitasi ekonomi dan eksploitasi seksual. Para penari tidak pernah merasa bahwa dirinya telah menjadi korban eksploitasi. Itu sudah menjadi resiko seorang penari. Tuntutan ekonomi menjadi penyebab utama para perempuan di Desa Selanegara menjalani profesi sebagai penari. Fenomena ini diharapkan dapat mendorong masyarakat dan pemerintah untuk mengembalikan lagi kesenian tradisional pada posisi yang lebih terhormat sehingga melindungi para pelaku kesenian dari tindakan eksploitasi.

\section{DAFTAR PUSTAKA}

Hadi, Y.S. 2005. Sosiologi Tari. Yogyakarta: Pustaka Pelajar.

Indriyanto. 2001. Kebangkitan Tari Rakyat Di Daerah Banyumas. Harmonia Jurnal Pengetahuan Dan Pemikiran Seni. 2 (2): 60-66.

Irianto, S. 2005. Perdagangan Perempuan Dalam Jaringan Narkoba. Jakarta: Yayasan Obor Indonesia.

Priyadi, S. 2003. Beberapa Karakter Orang Banyumas. Jurnal Bahasa Dan Seni. 31 (1): 30-48.

Ratih, E.M. \& Lestari, W. 2005. Citra Wanita dalam Pertunjukan Kesenian Tayub. Harmonia: Jurnal Pengetahuan Dan Pemikiran Seni. 6 (2)

Sagala, V. dan Rozana E. 2007. Memberantas Trafiking Perempuan dan Anak. Bandung : Pojok 85.

Sosan, I. 2010. Peran ganda ibu rumah tangga yang bekerja sebagai tukang ampelas kerajinan ukir. Jurnal Komunitas. 2 (2): 30-39.

Sunaryadi. 2000. Lengger. Tradisi dan Transformasi. Yogyakarta: Yayasan Untuk Indonesia.

Suraji, R. 2006. Religiusitas Tarian Lengger Desa Gerduren Kecamatan Purwojati Banyumas. Akademika, Jurnal Kebudayaan. 4 (1): 56-72.

Tukiran, \& Kosasih, A.D. 2007. Tanggapan Guru Sekolah Dasar Terhadap Pelaksanaan Pelajaran Muatan Lokal Budaya Banyumasan Di Sekolah Dasar. Jurnal Pendidikan Dasar. 8 (2): 60-85. 